\title{
Analisis Laporan Keuangan Pemerintah Daerah Kabupaten Subang
}

\author{
${ }^{1}$ Ai Siti Farida, ${ }^{2}$ Raden Faisal Maulana Nugraha
}

\author{
${ }^{1}$ Administrasi Publik Fakultas Ilmu Sosial dan Ilmu Politik UIN Sunan Gunung Djati Bandung; \\ aisitifarida@uinsgd.ac.id \\ ${ }^{2}$ Administrasi Publik Fakultas Ilmu Sosial dan Ilmu Politik UIN Sunan Gunung Djati Bandung; \\ faisalmaulana5@gmail.com
}

\begin{abstract}
The existence of regional autonomy requires each region to manage its finances independently. In its financial management, in 2014-2017 Subang District had several problems such as, the largest income was still from the balance fund which was a transfer from the Central Government, low capital expenditure, regional financial growth was at very low value, and inefficient local revenue. This study aims to find out how the financial performance of the Subang Regency Government in 2014-2017 was measured using regional financial ratios. This research is a qualitative descriptive study. In data collection researchers used the method of observation, interviews, and documentation. The type of data used is primary data from the Subang District Government Budget Realization Report 2014-2017. The results of the analysis show that the Financial Performance of the Subang Regency Government in terms of (1) The independence ratio shows that Subang Regency is very independent, because the average is $17.1 \%$ (2) The harmony ratio of the Subang Regency government is more likely to prioritize operational expenditure than capital expenditure. Large operating expenses are at an average of $73.75 \%$. While for capital expenditures at an average of $21.75 \%$ (3) Regional financial growth ratios can be said to be still very low, because the average is $8.6 \%$ (4) The efficiency ratio of local revenue can be said to be inefficient, because the average the efficiency rate is $63.3 \%$ (5) The effectiveness ratio of Subang Regency's original income has been effective, because the average effectiveness is above $100 \%$ which is $113.8 \%$.
\end{abstract}

Keywords: Regional Financial Performance, Independence Ratio, Harmony Ratio, Growth Ratio, PAD Efficiency Ratio, PAD Effectiveness Ratio.

\section{Pendahuluan}

Setiap Pemerintah daerah baik itu yang ada di tingkat provinsi, kabupaten, dan kota memiliki kewajiban untuk menyampaikan laporan pertanggungjawaban keuangan daerahnya secara berkala. Laporan pertanggung jawaban keuangan ini disusun sesuai aturan yang berlaku untuk dinilai apakah berhasil atau tidak dalam menjalankan tugasnya. Analisis laporan keuangan merupakan salah satu media atau cara yang dimaksdukan untuk melihat dan menilai kinerja pemerintah daerah dalam pengelolaan keuangannya. Di mana analisis laporan keuangan merupakan kegiatan untuk menginterpretasikan angka-angka dalam laporan keuangan dalam rangka menilai kinerja keuangan yang hasil dari analisis tersebut akan digunakan sebagai dasar pengambilan keputusan ekonomi, sosial, atau politik (Mahmudi, 2016). Analisis laporan keuangan ini berfokus pada laporan keuangan yang memanfaatkan sebuah teknik analisis untuk mengetahui dan memahami isu serta peluang yang ada sehingga akan sangat bermanfaat dalam upaya pengambilan suatu keputusan. 
Pelaporan keuangan bertujuan untuk menyediakan sejumlah data dan informasi yang memiliki kebermanfaatan bagi orang-orang yang berkepentingan maupun masyarakat pada umunya dalam mendorong prinsip-prinsip akuntabilitas seperti informasi tentang jumlah sumber daya keuangan yang digunakan dalam kegiatan pelaporan dan hasil yang diperoleh. Selain itu, juga berguna dalam rangka proses pembuatan keputusan baik itu dalam bidang sosial, politik, dan ekonomi karena dapat memberikan berbagai informasi mengenai sumber, pengalokasian, dan penggunaan sumber daya keuangan (Wahyu, 2015). Sementara tujuan pengukuran Kinerja Pengelolaan Keuangan Pemerintah Daerah menurut Mardiasmo dalam (Adhiantoko, 2013) adalah untuk meningkatkan kinerja pemerintah, pengukuran kinerja harus membantu pemerintah fokus pada tujuan dan sasaran program kerja sehingga pada akhirnya akan meningkatkan efisiensi penyediaan layanan publik, mengalokasikan sumber daya dan membuat keputusan, dan untuk mewujudkan akuntabilitas publik dan meningkatkan komunikasi kelembagaan.

Dalam rangka menjaga kualitas dan kredibilitas sebuah laporan keuangan, maka kegiatan analisis ini membutuhkan Teknik atau cara tertentu yang tepat supaya kegiatan analisis ini dapat berguna bagi para pemangku kebijakan dan pengambil keputusan. Ada beberapa teknik analisis untuk menganalisis laporan keuangan, yaitu diantaranya analisis varians, analisis rasio, analisis pertumbuhan, analisis regresi, dan analisis prediksi. Salah satu teknik yang sering digunakan adalah melakukan perhitungan menggunakan analisis rasio keuangan. Analisis rasio keuangan sendiri adalah merupakan perbandingan antara dua angka atau lebih yang datanya diambil dari elemen laporan keuangan. Analisis rasio keuangan dapat digunakan untuk menginterpretasikan perkembangan kinerja dari tahun ke tahun (Mahmudi, 2016).

Pertama, yaitu analisis rasio kemandirian dimana kemandirian suatu keuangan daerah mengindikasikan bahwa pemerintah daerah mamiliki kapasitas dan kapabilitas dalam mengelola dan mengurusi sendiri program, kegiatan, serta pelayanan kepada masyarakat. Kemandirian keuangan daerah dapat dilihat dari jumlah pendapatan asli daerahnya (PAD), juga yang berkaitan dengan sumber-sumber lainnya seperti bantuan atau pinjaman dari pemerintah di tingkat pusat (Halim, 2007). Cara menghitung suatu perbandingan kemandirian keuangan daerah yaitu dengan melakukan pembagian jumlah pendapatan asli daerah (PAD) dengan jumlah pendapatan yang berasal dari transfer pemerintah pusat dan provinsi serta pinjaman daerah. Semakin tinggi jumlah perbandingan maka semakin memperlihatkan bahwa daerah tersebut memiliki pengelolaan keuangan yang mandiri (Mahmudi, 2016). Sebagaimana tabel berikut ini:

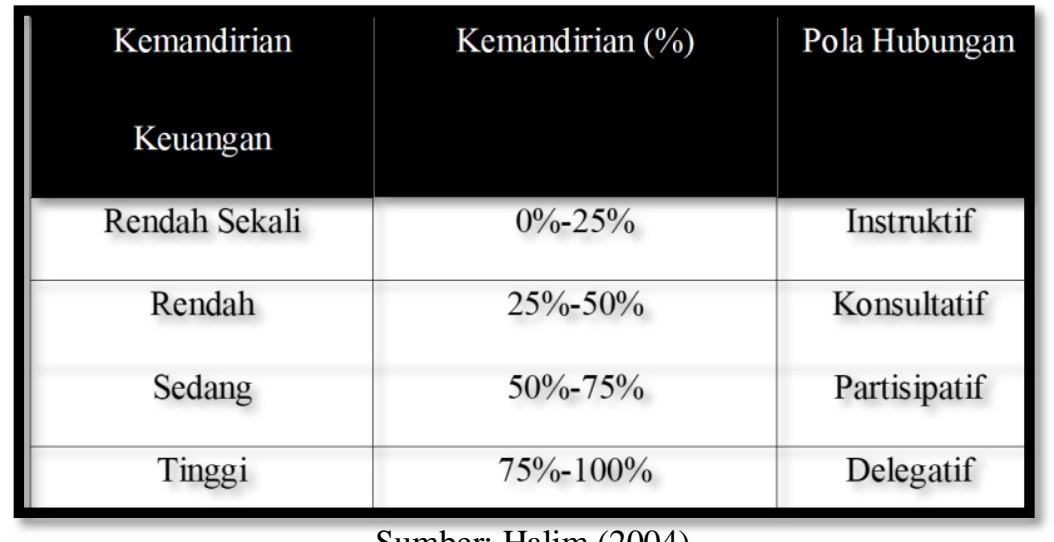

Sumber: Halim (2004) 
Kedua yaitu rasio efektivitas PAD, dimana tipe rasio ini menekankan pada kapabilitas pemerintah daerah untuk dapat mewujudkan PAD yang berkaitan dengan target yang sebelumnya telah direncanakan dan ditetapkan. Tentunya target ini atas dasar pertimbangan potensi dan kemampuan riil daerah tersebut. Penghitungan rasio efektivitas untuk PAD ini dilakukan dengan cara mengkomparasikan antara pendapatan PAD yang terealisasi dengan pendapatan PAD yang mencapai target (Mahmudi, 2016). Sebagaimana tabel rumus berikut ini:

$$
\text { Rasio efektivitas }=\frac{\text { Realisasi Penerimaan PAD }}{\text { Target Penerimaan PAD yang ditetapkan }} \times 100
$$

\begin{tabular}{|c|c|}
\hline Kriteria Efektivitas & Persentase Efektivitas (\%) \\
\hline Sangat Efektiv & $>100 \%$ \\
\hline Efektiv & $100 \%$ \\
\hline Cukup Efektiv & $90 \%-99 \%$ \\
\hline Kurang Efektiv & $75 \%-89 \%$ \\
\hline Tidak Efektiv & $<75 \%$ \\
\hline
\end{tabular}

Sumber: Mahmudi, 2016

Ketiga yaitu rasio efisiensi PAD, dimana rasio ini merupakan rasio yang mencerminkan hubungan diantara jumlah yang dihasilkan untuk mendapatkan penghasilan dan ketercapaian penghasilan yang diperoleh. Kinerja pemerintah daerah dalam laporan laba rugi dapat dikategorikan efektif jika rasio yang diperoleh adalah kurang dari $100 \%$ atau kurang dari satu. Rasio efisiensi yang semakin kecil, maka menunjukkan kinerja pemerintah daerah yang semakin baik. Sebagaimana tabel rumus berikut ini:

$$
\text { Rasio Efisiensi PAD }=\frac{\text { biaya pemerolehan PAD }}{\text { Ralisasi Penerimaan PAD }} \times 100
$$

\begin{tabular}{|c|c|}
\hline Kriteria Efisiensi & Persentase Efisiensi (\%) \\
\hline Sangat Tidak Efisien & $>40 \%$ \\
\hline Kurang Efisien & $31 \%-40 \%$ \\
\hline Cukup Efisien & $21 \%-30 \%$ \\
\hline Efisiensi & $10 \%-20 \%$ \\
\hline Sangat Efisien & $<10 \%$ \\
\hline
\end{tabular}

Sumber: (Mahmudi, 2016)

Keempat yaitu rasio keserasian yang membahas mengenai belanja operasi, dimana rasio ini merupakan perbandingan dari total biaya operasional dan pengeluaran daerah. Hubungan ini dimaksudkan untuk menginformasikan kepada setiap pengguna atau pihak yang berkepentingan mengenai laporan tentang bagian-bagian pengeluaran daerah yang 
didistribusikan untuk pengeluaran operasional. Belanja operasional sendiri merupakan jenis belanja yang kebermanfaatannya dirasakan dalam kurun waktu satu tahun keuangan. Sehingga hal tersebut bersifat jangka pendek dan pada beberapa kasus dapat berjalan secara kontinu dan konsisten. Berikut ini merupakan rumus dari rasio belanja operasi:

Rasio Belanja modal sendiri merupakan komparasai antara jumlah keseluruhan belanja modal yang terealisasi dengan jumlah keseluruhan belanja daerah. Berdasarkan pada tipe rasio ini, setiap pengguna laporan dapat melihat dengan jelas bagian dari pengeluaran daerah yang diperuntukkan untuk investasi dalam bentuk belanja modal pada tahun anggaran yang bersangkutan. Rasio belanja modal ini dirumuskan sebagai berikut:

$$
\text { Rasio Belanja Modal }=\frac{\text { Realisasi Total Belanja Modal }}{\text { Total Belanja }}
$$

Kelima, yaitu rasio pertumbuhan yang menilai seberapa mampu pemerintah daerah untuk menjaga konsistensi serta memperbaiki capaian-capaian yang sudah baik dan yang belum optimal dari satu periode ke periode berikutnya. Pentingnya pemahaman tentang rasio pertumbuhan untuk setiap komponen sumber pendapatan dan pengeluaran ini adalah untuk menilai potensi dan hasil yang telah dicapai sehingga kedepan membutuhkan perhatian dan tindak lanjut (Halim, 2007). Rasio pertumbuhan dapat dinilai menggunakan rumus dan kriteria seperti berikut:

$$
\text { Rasio Pertumbuhan }=\frac{P n-P o}{P o} \times 100
$$

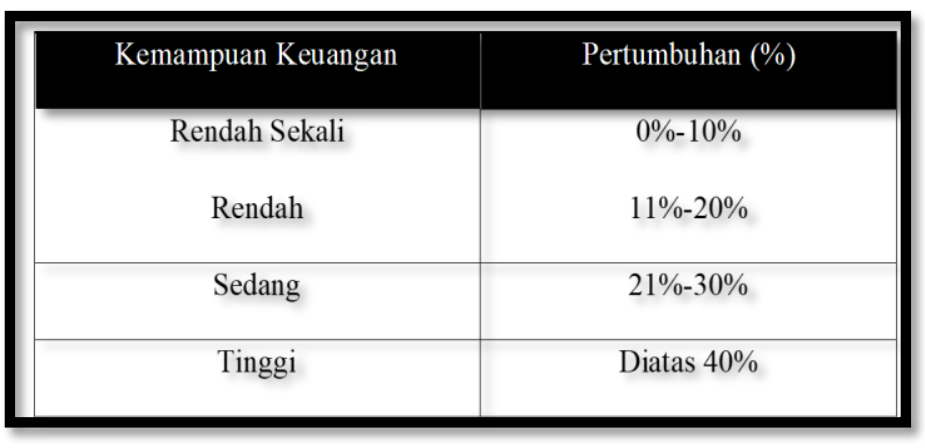

Sumber: Dajan dalam Jurnal (Utomo, 2011)

Kabupaten Subang ialah salah satu daerah otonom yang sedang berkembang di Jawa Barat. Hal tersebut adalah implikasi dari sejumlah kebijakan dan program pembangunan pemerintahan daerahnya. Pembangunan merupakan bagian dari sekian program yang ada pada pemerintah Kabupaten Subang yang mendapatkan perhatian dan daya Tarik cukup besar dari masyarakat Subang itu sendiri. Beberapa diantaranya dapat dilihat dari sejumlah program pembangunan seperti perbaikan disepanjang jalan raya utama, pembangunan berbagai macam taman kota, dan yang tidak kalah pentingnya adalah pembangunan tempat-tempat wisata alam yang baru. Tentu hal ini menjadi sebuah perhatian untuk masyarakat luas.

Pujian pun dilontarkan oleh Kementerian Dalam Negeri Republik Indonesia melalui penerimaan penghargaan atas kinerja status Sangat Tinggi (ST) bintang 3 dalam pelaksanaan Pemerintahan Daerah berdasarkan Laporan Penyelenggaraan Pemerintah Daerah (LPDD) Tahun 2016 (Tintahijau.com, 2018). Selain itu, jika mengacu kepada laporan keuangan Pemkab Subang dalam lima tahun beruntun menunjukkan hasil yang positif. Sesuai yang tertera pada gambar: 


$$
\text { Rasio Belanja Operasi }=\frac{\text { Realisasi Total Belanja 0perasi }}{\text { Total Belanja }}
$$

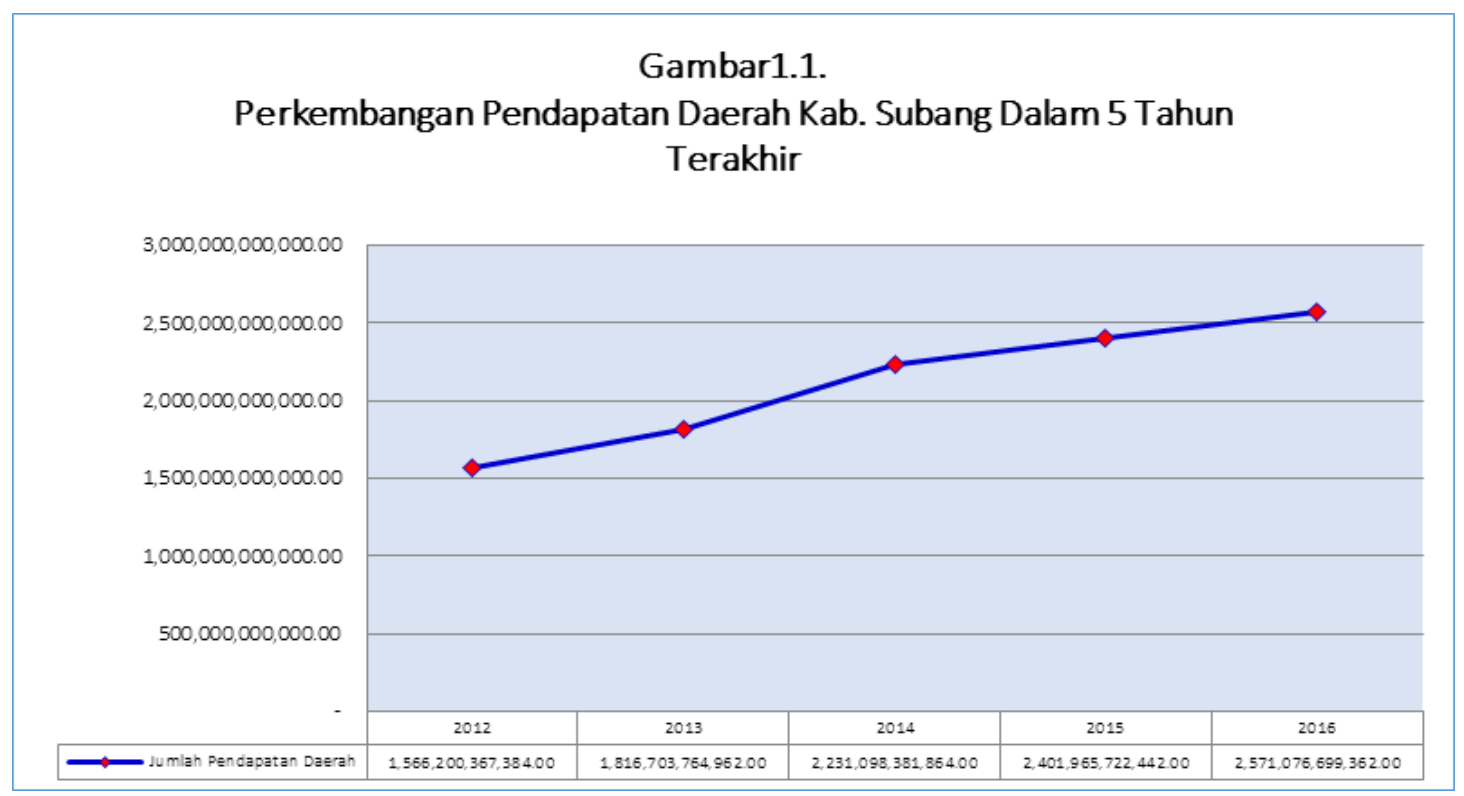

Sumber : DPPKAD Kab. Subang, 2016

Berdasarkan grafik tersebut bahwa pendapatan daerah Kabupaten Subang mengalami peningkatan yang signifikan dalam kurun waktu lima tahun terakhir. Peningkatan pendapatan daerah setiap tahun terjadi pada semua pos pendapatan, yaitu pos PAD, lain-lain pendapatan yang sah serta dana perimbangan. Namun dibalik itu, ada beberapa permasalahan yang dihadapi oleh pemerintah daerah kabupaten Subang.

Masalah Pertama yaitu pendapatan terbesar masih dari Dana Perimbangan yang merupakan transferan dari Pemerintah Pusat. Sedangkan kontribusi PAD terhadap APBD sebagai potret kemandirian daerah dan efektivitas otonomi daerah masih sangat kecil dibawah $15 \%$.

\begin{tabular}{|c|c|c|c|c|}
\hline Tahun & $\begin{array}{c}\text { Biaya pemerolehan } \\
\text { PAD }\end{array}$ & Realisasi PAD & Persentase & Nilai \\
\hline 2014 & $162.371 .817 .986,00$ & $262.619 .476 .530,00$ & 61.83 & Tidak Efisien \\
\hline 2015 & 215.869.694.978,00 & $314.047 .989 .351,00$ & 68.74 & Tidak Efisien \\
\hline 2016 & $301.951 .911 .754,00$ & $360.621 .220 .370,00$ & 83.73 & Tidak Efisien \\
\hline 2017 & $228.133 .011 .195,00$ & $581.810 .550 .070,00$ & 39.21 & Kurang Efisien \\
\hline
\end{tabular}

Sumber: LRA kabupaten Subang (diolah) 
Masalah kedua, dalam rasio keserasian modal pemerintah kabupaten Subang untuk tahun 2014-2015 mengalami peningkatan walaupun tidak begitu signifikan. Namun di tahun 2016 justru mengalami stagnan dan bahkan tahun 2017 mengalami penurunan. Hal tersebut tertera pada tabel:

\begin{tabular}{|c|c|c|c|}
\hline Tahun & Belanja Modal & Total Belanja & Persentase \\
\hline 2014 & 484.223 .520 .521 & 2.169 .100 .504 .872 & $22 \%$ \\
\hline 2015 & 479.480 .492 .144 & 2.114 .883 .423 .167 & $23 \%$ \\
\hline 2016 & 524.265 .605 .647 & 2.262 .396 .564 .685 & $23 \%$ \\
\hline 2017 & 486.430 .787 .962 & 2.502 .250 .774 .730 & $19 \%$ \\
\hline
\end{tabular}

Sumber: LRA kabupaten Subang (diolah)

Masalah ketiga, pada rasio pertumbuhan keuangan daerah pemerintah kabupaten Subang untuk tahun 2015-2017 mengalami peningkatan pada setiap tahunnya. Akan tetapi peningkatan tersebut masih pada nilai kriteria yang sangat rendah, sebagai yang terdapat dalam tabel:

\begin{tabular}{|c|c|c|c|c|}
\hline Tahun & PAD Kab. Subang & $\begin{array}{c}\text { Bantuan dari Pusat dan } \\
\text { Provinsi }\end{array}$ & Persentase & Nilai \\
\hline $\mathbf{2 0 1 4}$ & $262.619 .476 .530,00$ & $1.968 .478 .953 .458,00$ & $13,34 \%$ & Rendah Sekali \\
\hline $\mathbf{2 0 1 5}$ & $314.047 .989 .351,00$ & $2.087 .917 .733 .091,00$ & $15,04 \%$ & Rendah Sekali \\
\hline $\mathbf{2 0 1 6}$ & $360.621 .220 .370,00$ & $2.470 .660 .190 .590,00$ & $14,60 \%$ & Rendah Sekali \\
\hline $\mathbf{2 0 1 7}$ & $581.810 .550 .070,00$ & $2.282 .430 .023 .762,00$ & $25,49 \%$ & Rendah \\
\hline
\end{tabular}

Sumber: LRA kabupaten Subang (diolah)

Masalah keempat, pada rasio efisiensi PAD Pemerintah Kabupaten Subang untuk Tahun 2014-2016 mengalami peningkatan. Yang berarti peningkatan tersebut menandakan tidak efisiensinya dalam mengelola penerimaan PAD, sebagai mana tertera dalam tabel berikut: 


\begin{tabular}{|c|c|c|c|c|}
\hline Tahun & Total pendapatan & Total Belanja & Pn-p0 & Persentase \\
\hline $\mathbf{2 0 1 4}$ & 2.231 .098 .381 .864 & 2.169 .100 .504 .872 & 4.400 .198 .886 .736 & - \\
\hline $\mathbf{2 0 1 5}$ & 2.401 .803 .549 .942 & 2.114 .883 .423 .167 & 4.516 .686 .973 .109 & $3 \%$ \\
\hline $\mathbf{2 0 1 6}$ & 2.571 .077 .097 .133 & 2.262 .396 .564 .685 & 4.833 .473 .661 .818 & $7 \%$ \\
\hline $\mathbf{2 0 1 7}$ & 2.864 .240 .573 .832 & 2.502 .250 .774 .730 & 5.366 .491 .348 .562 & $11 \%$ \\
\hline
\end{tabular}

Sumber: LRA kabupaten Subang (diolah)

Dari uraian latar belakang tersebut, maka penelitian ini bertujuan untuk menganalisis kinerja keuangan Pemerintah Kabupaten Subang tahun 2014-2017 yang diukur dengan menggunakan rasio keuangan daerah.

\section{Metode Peneltian}

Penelitian ini menggunakan metode deskriptif dengan pendekatan kualitatif. Metode deskriptif-kualitatif sesuai untuk penelitian yang akan dilakukan ini, di mana peneliti berusaha untuk mendeskripsikan hasil analisis rasio keuangan Pemerintah daerah Kabupaten Subang. Populasi dalam penelitian ini adalah Laporan Keuangan Pemerintah Daerah (LKPD) Kabupaten Subang. Dalam menentukan sampel, peneliti menggunakan sampling purposive yang bertujuan untuk mengambil sampel dengan pertimbangan tertentu dan memenuhi kriteria tertentu. Sampel dari penelitian yang akan dilakukan ini adalah laporan keuangan pemerintah daerah (LKPD) Kabupaten Subang berupa laporan realisasi anggaran tahun 2014-2017.

Dalam penelitian ini, peneliti menggunakan dua sumber data, yaitu pertama data primer yang berasal dari observasi dan wawancara mendalam pada BKAD Kabupaten Subang. Wawancara tersebut dilakukan kepada 3 orang responden yakni Casari (Kasubid Pelaporan Bidang Akuntansi Pelaporan), Deden Sujatnika (Kasubid Penagihan Pajak Daerah Lainnya), dan Bay Zainatuddaroin (Kasubid Akuntansi Aset, Investasi dan Persediaan) pada tanggal 22 April 2019, dengan masing-masing sembilan pertanyaan. Kedua, yaitu data sekunder yang diperoleh dari studi pustaka, buku, internet, jurnal yang dapat membantu melangkapi kajian proses penelitian. Dalam melakukan analisis data, peneliti menggunakan teknik analisis data dari Miles dan Huberman, yaitu pengumpulan data yang dilakukan dengan cara observasi dan wawancara, reduksi data, penyajian data, dan penarikan kesimpulan atau verifikasi.

\section{Hasil Dan Pembahasan}

A. Kinerja Keuangan Pemerintah Kabupaten Subang Tahun 2014-2017 berdasarkan Rasio Kemandirian PAD

Rasio Kemandirian Keuangan Daerah dapat dirumuskan sebagai berikut:

$$
\text { Rasio Kemandirian }=\frac{\text { Pendapatan Asli Daerah }}{\text { Trasnfer Pusat atau Provinsi dan pinjaman }} \times 100
$$


Berikut perhitungan Rasio Kemandirian keuangan daerah kabupaten Subang Tahun Anggaran 2014-2017:

$$
\begin{aligned}
\text { Rasio Kemandirian } 2014 & =\frac{262.619 .476 .530}{1.968 .478 .953 .458} \times 100 \\
& =13.34 \% \\
\text { Rasio Kemandirian } 2015 & =\frac{314.047 .989 .351}{2.087 .917 .733 .091} \times 100 \\
& =15.04 \% \\
\text { Rasio Kemandirian } 2016 & =\frac{360.621 .220 .370}{2.470 .660 .190 .590} \times 100 \\
& =14.60 \% \\
\text { Rasio Kemandirian } 2017 & =\frac{581.810 .550 .070}{2.282 .430 .023 .762} \times 100 \\
& =25.49 \%
\end{aligned}
$$

Adapun hasil dari analisis rasio kemandirian keuangan daerah Kabupaten Subang tertera dalam tabel berikut:

\begin{tabular}{|c|c|c|c|c|}
\hline \multicolumn{2}{|c|}{ Tahun } & PAD Kab. Subang & Bantuan dari Pusat dan & Persentase \\
& & \multicolumn{2}{c|}{ Provinsi } & \\
\hline $\mathbf{2 0 1 4}$ & $262.619 .476 .530,00$ & $1.968 .478 .953 .458,00$ & $13,34 \%$ & Rendah Sekali \\
\hline $\mathbf{2 0 1 5}$ & $314.047 .989 .351,00$ & $2.087 .917 .733 .091,00$ & $15,04 \%$ & Rendah Sekali \\
\hline $\mathbf{2 0 1 6}$ & $360.621 .220 .370,00$ & $2.470 .660 .190 .590,00$ & $14,60 \%$ & Rendah Sekali \\
\hline $\mathbf{2 0 1 7}$ & $581.810 .550 .070,00$ & $2.282 .430 .023 .762,00$ & $25,49 \%$ & Rendah \\
\hline
\end{tabular}

Sumber: LRA kabupaten Subang (diolah)

Berdasarkan hasil perhitungan Rasio Kemandirian PAD Kabupaten Subang menunjukkan bahwa kemandirian Kabupaten Subang masih instruktif yang berarti masih bergantung kepada bantuan dari pusat dan provinsi. Dalam tiga tahun berturut-turut, PAD dan bantuan dari pusat mengalami peningkatan yaitu pada tahun 2014-2016. Bahkan PAD Kabupaten Subang selama empat tahun berturut-turut mengalami peningkatan yang cukup signifikan, yaitu pada tahun 2014 PAD yang terealisasi mencapai Rp. 262.619.476.530. Tahun 2015 PAD yang dicapai oleh Kabupaten Subang mencapai Rp. 314.047.989.351. Tahun berikutnya 2016 sebesar Rp. 360.621.220.370. Dan pada tahun 2017 PAD yang dicapai oleh Kabupaten Subang mengalami peningkatan yang signifikan, yaitu sebesar Rp. 581.810.550.070. Jika hanya dilihat dari pencapaian PAD, maka Kabupaten Subang mendapat nilai yang baik karena setiap tahunnya PAD yang dicapai terus mengalami penigkatan. Namun untuk melihat kinerja keuangan Pemerintah Daerah Kabupaten Subang berdasarkan rasio 
kemandirian PAD tidak hanya dilihat dari pencapaian PAD dari tahun ke tahun, akan tetapi harus dilihat juga perbandingan dengan bantuan dari pemerintah pusat dan provinsi.

Bantuan dari pemerintah pusat maupun provinsi yang relatif besar menjadi sebuah permasalahan tersendiri untuk kemandirian Kabupaten Subang. Berdasarkan tabel di atas dapat dilihat bahwa bantuan dari pemerintah pusat dan provinsi kepada Pemerintah Kabupaten Subang sebesar Rp. 1.968.478.953.458 pada tahun 2014. Pada tahun 2015 bantuan tersebut mengalami peningkatan menjadi Rp. 2.087.917.733.091. pada tahun berikutnya bantuan dari pemerintah pusat dan provinsi kembali mengalami peningkatan menjadi Rp. 2.470.660.190.590. Namun pada tahun 2017 mengalami penurunan dari tahun 2016 menjadi sebesar Rp. 2.282.430.023.762. Hal tersebut mengakibatkan kemandirian Kabupaten Subang berada pada titik 13,34\%. Tahun berikutnya pada tahun 2015 pada titik 15,04\%. Pada tahun 2016 mengalami penurunan kembali menjadi 14,6\%. Walaupun pada ahun 2017 mengalami kenaikan menjadi $25,49 \%$, namun hal itu tetap masih berada pada posisi rendah. Jadi, kinerja keuangan Kabupaten Subang berdasarkan rasio kemandirian daerah secara keseluruhan berada pada posisi rendah, hal ini menggambarkan bahwa tingkat ketergantungan daerah terhadap bantuan dari pemerintah pusat dan provinsi masih tinggi.

B. Kinerja Keuangan Pemerintah Kabupaten Subang Tahun 2014-2017 berdasarkan Rasio Keserasian

Analisis rasio keserasian dapat dilakukan dengan cara sebagai berikut:

$$
\begin{gathered}
\text { Rasio Belanja Operasional }=\frac{\text { Realisasi Total Belanja Operasional }}{\text { Total Belanja }} \times 100 \\
\text { Rasio Belanja Modal }=\frac{\text { Realisasi Total Belanja Modal }}{\text { Total Belanja }} \times 100
\end{gathered}
$$

Berikut hasil dari perhitungan rasio keserasian (belanja operasional) Kabupaten Subang tahun anggaran 2014-2017:

$$
\begin{aligned}
\text { Rasio Belanja Operasional 2014 } & =\frac{1.306 .896 .236 .815}{2.169 .100 .504 .872} \times 100 \\
& =60 \% \\
\text { Rasio Belanja Operasional 2015 } & =\frac{1.633 .934 .742 .364}{2.114 .883 .423 .167} \times 100 \\
& =77 \% \\
\text { Rasio Belanja Operasional 2016 } & =\frac{1.735 .172 .298 .750}{2.262 .396 .564 .685} \times 100 \\
& =77 \% \\
\text { Rasio Belanja Operasional 2017 } & =\frac{2.015 .180 .259 .588}{2.502 .250 .774 .730} \times 100 \\
& =81 \%
\end{aligned}
$$


Adapun hasil perhitungan Rasio Keserasian (Belanja Operasional) Kabupaten Subang tercantum pada tabel berikut:

\begin{tabular}{|c|c|c|c|}
\hline Tahun & $\begin{array}{c}\text { Belanja } \\
\text { Operasional }\end{array}$ & Total Belanja & Persentase \\
\hline $\mathbf{2 0 1 4}$ & 1.306 .896 .236 .815 & 2.169 .100 .504 .872 & $60 \%$ \\
\hline $\mathbf{2 0 1 5}$ & 1.633 .934 .742 .364 & 2.114 .883 .423 .167 & $77 \%$ \\
\hline $\mathbf{2 0 1 6}$ & 1.735 .172 .298 .750 & 2.262 .396 .564 .685 & $77 \%$ \\
\hline $\mathbf{2 0 1 7}$ & 2.015 .180 .259 .588 & 2.502 .250 .774 .730 & $81 \%$ \\
\hline
\end{tabular}

Sumber: LRA kabupaten Subang (diolah)

Pada tabel di atas, dapat dilihat persentase belanja operasi Kabupaten Subang selama empat tahun beruntun selalu mengalami peningkatan. Pada tahun 2014 belanja operasi mencapai Rp. 1.306.896.236.815 atau 60\% dari total belanja. Pada tahun 2015 belanja operasi meningkat menjadi Rp. 1.633.934.742.364 atau 77\% dari keseluruhan belanja. Adapun pada tahun 2016 belanja operasi sebesar Rp. 1.73.5172.298.750 atau masih tetap berada pada 77\% dari belanja keseluruhan. Dan pada tahun 2017 kembali mengalami kenaikan menjadi sebesar Rp. 2.015.180.259.588 atau menjadi 81\% dari keseluruhan belanja. Walaupun secara persentase pada tahun 2015 dan 2016 berada pada posisi yang sama yaitu 77\%, tapi secara nominal belanja operasi pada setiap tahunnya selalu mengalami peningkatan.

Adapun perhitungan Rasio Keserasian (Belanja Modal) dapat dilihat dari tabel berikut:

$$
\begin{aligned}
\text { Rasio Belanja Modal 2014 }= & \frac{484.223 .520 .521}{2.169 .100 .504 .872} \times 100 \\
& =22 \% \\
\text { Rasio Belanja Modal 2015 } & =\frac{479.480 .492 .144}{2.114 .883 .423 .167} \times 100 \\
& =23 \% \\
\text { Rasio Belanja Modal 2016 } & =\frac{524.265 .605 .647}{2.262 .396 .564 .685} \times 100 \\
& =23 \% \\
\text { Rasio Belanja Modal 2017 } & =\frac{486.430 .787 .962}{2.502 .250 .774 .730} \times 100 \\
& =19 \%
\end{aligned}
$$


Berikut hasil dari perhitungan Rasio Keserasian (Belanja Modal) Kabupaten Subang Tahun Anggaran 2014-2017 dapat dilihat pada tabel berikut:

\begin{tabular}{|c|c|c|c|}
\hline Tahun & Belanja Modal & Total Belanja & Persentase \\
\hline 2014 & 484.223 .520 .521 & 2.169 .100 .504 .872 & $22 \%$ \\
\hline 2015 & 479.480 .492 .144 & 2.114 .883 .423 .167 & $23 \%$ \\
\hline 2016 & 524.265 .605 .647 & 2.262 .396 .564 .685 & $23 \%$ \\
\hline 2017 & 486.430 .787 .962 & 2.502 .250 .774 .730 & $19 \%$ \\
\hline
\end{tabular}

Sumber: LRA kabupaten Subang (diolah)

Pada tabel tersebut, terlihat belanja modal Kabupaten Subang secara persentase berada pada titik 22\% dari total belanja atau sebesar Rp. 484.223.520.521 pada tahun 2014. Pada tahun 2015 secara nominal mengalami penurunan menjadi Rp. 479.480.492.144 atau 23\% dari total belanja. Pada tahun berikutnya belanja modal mengalami kenaikan kembali menjadi Rp. 524.265.605.647 namun secara persentase berada pada 23\% dari total belanja. Adapun pada tahun 2017 belanja modal mengalami penurunan kembali menjadi Rp. 486.430.787.962 atau sebesar $19 \%$ dari total belanja.

Meskipun pada saat ini, penggunaan belanja modal dan belanja operasional belum ada standar yang diterapkan oleh pemerintah maupun belum ada standar penialian yang dikemukakan oleh para ahli, sehingga walaupun belanja operasional lebih besar dari pada belanja modal hal ini belum bisa dikatakan hal yang kurang baik.

C. Kinerja Keuangan Pemerintah Kabupaten Subang Tahun 2014-2017 berdasarkan Rasio Pertumbuhan Keuangan Daerah

Adapun rumus untuk mengetahui nilai rasio pertumbuhan adalah:

$$
\text { Rasio Pertumbuhan } / r=\frac{p n-p 0}{p 0} \times 100
$$

Keterangan: $\mathrm{Pn}=$ Pendapatan, Belanja, yang dihitung tahun $n$

Po = Pendapatan, Belanja, yang dihitung tahun 0 (Tahun

sebelumnya)

$\mathrm{r} \quad=$ Rasio pertumbuhan 
Berikut perhitungan Rasio Pertumbuhan Pemerintah Kabupaten Subang tahun 20152017:

$$
\begin{aligned}
\mathrm{r}(\text { Belanja) } 2014-2015 & =\frac{2.114 .883 .423 .167-2.169 .100 .504 .872}{2.169 .100 .504 .872} \times 100 \\
& =-2,5 \% \\
\mathrm{r}(\text { Belanja) } 2015-2016 & =\frac{2.262 .396 .564 .685-2.114 .883 .423 .167}{2.114 .883 .423 .167} \times 100 \\
& =7 \% \\
\mathrm{r}(\text { Belanja) } 2016-2017 & =\frac{2.502 .250 .774 .730-2.262 .396 .564 .685}{2.262 .396 .564 .685} \times 100 \\
& =10,6 \% \\
\mathrm{r}(\text { Pendapatan }) 2014-2015 & =\frac{2.401 .803 .549 .942-2.231 .098 .381 .864}{2.231 .098 .381 .864} \times 100 \\
& =7,6 \% \\
\mathrm{r}(\text { Pendapatan }) 2015-2016 & =\frac{2.571 .077 .097 .133-2.401 .803 .549 .942}{2.401 .803 .549 .942} \times 100 \\
& =7 \% \\
\mathrm{r}(\text { Pendapatan }) 2016-2017 & =\frac{2.864 .240 .573 .832-2.571 .077 .097 .133}{2.571 .077 .097 .133} \times 100 \\
& =11,4 \%
\end{aligned}
$$

\begin{tabular}{|c|c|c|c|c|}
\hline Tahun & Total Belanja (Pn) & $\begin{array}{c}\text { Total Belanja } \\
(\mathbf{P o})\end{array}$ & Pn-p0 & Persentase \\
\hline 2015 & 2.114.883.423.167 & 2.169.100.504.872 & -54.217 .081 .705 & $-2,5 \%$ \\
\hline 2016 & 2.262 .396 .564 .685 & 2.114 .883 .423 .167 & 147.513 .141 .518 & $7 \%$ \\
\hline 2017 & 2.502 .250 .774 .730 & 2.262 .396 .564 .685 & 239.854 .210 .045 & $10,6 \%$ \\
\hline
\end{tabular}

Berikut hasil perhitungan Rasio Pertumbuhan Kabupaten Subang Tahun Anggaran 2015-2017:

Sumber: LRA kabupaten Subang (diolah)

Berdasarkan hasil perhitungan rasio belanja yang tertera pada tabel di atas, bahwa belanja Pemerintah Kabupaten Subang mengalami penurunan pada tahun 2015 namun terjadi peningkatan selama tiga tahun berikutnya. Pada tahun 2014, Pemerintah Kabupaten Subang mengeluarkan dana belanja sebesar Rp. 2.169.100.504.872. pada tahun 2015 mengalami penurunan sebesar $-2,5 \%$ menjadi Rp. 2.114.883.423.167. Namun pada tahun berikutnya mengalami peningkatan sebesar 7\% menjadi Rp. 2.262.396.564.685. Begitupun pada tahun 2017 menglami peningkatan kembali sebesar 10,6\% belanja Pemerintah Kabupaten Subang menjadi Rp. 2.502.250.774.730. 


\begin{tabular}{|c|c|c|c|c|}
\hline Tahun & $\begin{array}{c}\text { Total pendapatan } \\
(\mathbf{P n})\end{array}$ & $\begin{array}{c}\text { Total Pendapatan } \\
(\mathbf{P o})\end{array}$ & Pn-p0 & Persentase \\
\hline $\mathbf{2 0 1 5}$ & 2.401 .803 .549 .942 & 2.231 .098 .381 .864 & 170.705 .168 .078 & $7,6 \%$ \\
\hline $\mathbf{2 0 1 6}$ & 2.571 .077 .097 .133 & 2.401 .803 .549 .942 & 169.273 .547 .191 & $7 \%$ \\
\hline $\mathbf{2 0 1 7}$ & 2.864 .240 .573 .832 & 2.571 .077 .097 .133 & 293.163 .476 .699 & $11,4 \%$ \\
\hline
\end{tabular}

Sumber: LRA kabupaten Subang (diolah)

Berdasarkan tabel tersebut sesuai dengan hasil perhitungan pendapatan bahwa pendapatan Pemerintah Kabupaten Subang selalu mengalami peningkatan. Pada tahun 2014 realisasi pendapatan Pemerintah Kabupaten Subang sebesar Rp. 2.231.098.381.864. Pada tahun 2015 mengalami peningkatan sebesar 7,6\% yaitu menjadi Rp. 2.401.803.549.942. Pada tahun 2016 mengalami peningkatan kembali, namun peningkatan tersebut lebih kecil dari tahun sebelumnya, yaitu sebesar 7\% menjadi Rp. 2.571.077.097.133. Sedangkan pada tahun berikutnya mengalami peningkatan yang lebih tinggi dari tahun-tahun sebelumnya, yaitu sebesar 11,4\% menjadi Rp. 2.864.240.573.832. Adapun kenapa pertumbuhan keuangan pemerintah daerah Kabupaten Subang rendah, terutama dalam pertumbuhan pendapatan setiap tahunnya adalah dikarenakan di antaranya tidak semua SKPD itu memiliki penerimaan.

Berdasarkan dari uraian di atas dapat diketahui bahwa Pemerintah Kabupaten Subang selalu melakukan perkembangan untuk mencapai target pendapatan pada setiap tahunnya. Namun pada tahun 2017, dengan meningkatnya capaian target pendapatan justru disertai juga dengan meningkatnya belanja daerah yang cukup tinggi yaitu sebesar 10,6\%. Sedangkan pada tahun 2015 cukup baik meskipun realisasi pendapatan berkembang hanya $7 \%$ tetapi disertai dengan menurunnya belanja sebesar $2,5 \%$.

D. Kinerja Keuangan Pemerintah Kabupaten Subang Tahun 2014-2017 berdasarkan Rasio Efisiensi Pendapatan Asli Daerah

Dalam melakukan analisis rasio ini dapat dilakukan dengan menggunakan rumus sebagai berikut:

$$
\text { Rasio Efisiensi PAD }=\frac{\text { biaya pemerolehan PAD }}{\text { Realisasi Penerimaan PAD }} \times 100
$$


Berikut perhitungan dari rasio efisiensi PAD Kabupaten Subang tahun anggaran 20142017:

$$
\begin{aligned}
\text { Rasio Efisiensi } 2014 & =\frac{162.371 .817 .986,00}{262.619 .476 .530,00} \times 100 \\
& =61,83 \% \\
\text { Rasio Efisiensi } 2015 & =\frac{215.869 .694 .978,00}{314.047 .989 .351,00} \times 100 \\
& =68,74 \% \\
\text { Rasio Efisiensi } 2016 & =\frac{301.951 .911 .754,00}{360.621 .220 .370,00} \times 100 \\
& =83,73 \% \\
\text { Rasio Efisiensi } 2017 & =\frac{228.133 .011 .195,00}{581.810 .550 .070,00} \times 100 \\
& =39,21 \%
\end{aligned}
$$

\begin{tabular}{|c|c|c|c|c|}
\hline Tahun & Biaya pemerolehan PAD & Realisasi PAD & Persentase & Nilai \\
\hline 2014 & $162.371 .817 .986,00$ & $262.619 .476 .530,00$ & 61.83 & Tidak Efisien \\
\hline 2015 & $215.869 .694 .978,00$ & $314.047 .989 .351,00$ & 68.74 & Tidak Efisien \\
\hline 2016 & $301.951 .911 .754,00$ & $360.621 .220 .370,00$ & 83.73 & Tidak Efisien \\
\hline 2017 & $228.133 .011 .195,00$ & $581.810 .550 .070,00$ & 39.21 & Kurang Efisien \\
\hline
\end{tabular}

Berikut hasil perhitungan Rasio Efisiensi PAD Kabupaten Subang Tahun Anggaran 2014-2017 dapat dilihat pada tabel berikut:

Sumber: LRA kabupaten Subang (diolah)

Berdasarkan tabel tersebut dapat diketahui kinerja Pemerintah Kabupaten Subang berdasarkan rasio efisiensi PAD dapat dinilai kurang baik. Terlihat pencapaian PAD setiap tahun mengalami peningkatan namun diiringi dengan biaya yang relatif tinggi. Pada tahun 2014 yang direalisasikan mencapai Rp. 206.423.025.875 dengan biaya yang dikeluarkan sebesar Rp. 262.619.476.530. Yang berarti tingkat efisiensi PAD Kabupaten Subang pada titik 61.8\% dengan nilai tidak efisien. Tahun 2015 realisasi PAD meningkat menjadi Rp. 314.047.989.351 dengan biaya Rp. 215.869.694.978 sehingga nilai efisiensi PAD berada pada titik $68.7 \%$ dengan nilai tidak efisien. Pada tahun berikutnya realisasi PAD mengalami peningkatan kembali sebesar Rp. 360.621.220.370 dengan biaya pemerolehan sebesar Rp. 301.951.911.754 itu artinya efisiensi PAD pada tahun 2016 ini berada pada titik $83.7 \%$ dengan nilai efisiensi tidak efisien. Dan pada tahun 2017 lagi-lagi realisasi PAD mengalami peningkatan sebesar Rp. 581.810.550.070 dengan biaya yang dikeluarkan sebesar Rp. 228.133.011.195 sehingga tingkat efisiensi PAD berada pada titik $39.2 \%$ yang artinya nilai ini lebih baik dari tiga tahun sebelumnya dan berapa pada nilai kurang efisien. 
Hal tersebut dapat terjadi demikian dikarekan berbagai faktor, di antaranya untuk menyiapkan sarana dan pra sarana. Selain itu, faktor dari SKPD yang tidak memiliki penerimaan dan bahkan dalam menjalankan belanja operasionalnya dapat dikatakan relatif tinggi pun mempengaruhi dalam efisiensi penerimaan PAD.

E. Kinerja Keuangan Pemerintah Kabupaten Subang Tahun 2014-2017 berdasarkan Rasio Efektivitas Pendapatan Asli Daerah

Adapun rumus untuk menghitung Rasio Efektivitas PAD adalah:

$$
\text { Rasio Efisiensi PAD 2014 }=\frac{\text { Realisasi Penerimaan PAD }}{\text { Target Penerimaan PAD yang ditetapkan }} \times 100
$$

2017:

Berikut perhitungan Rasio Efektivitas PAD Kabupaten Subang tahun anggaran 2014-

$$
\begin{aligned}
\text { Rasio Efisiensi PAD 2014 } & =\frac{262.619 .476 .530}{206.423 .025 .875} \times 100 \\
& =127,22 \% \\
\text { Rasio Efisiensi PAD 2015 } & =\frac{314.047 .989 .351}{281.201 .689 .946} \times 100 \\
& =111,68 \% \\
\text { Rasio Efisiensi PAD 2016 } & =\frac{360.621 .220 .370}{326.015 .455 .956} \times 100 \\
& =110,61 \% \\
\text { Rasio Efisiensi PAD 2017 } & =\frac{581.810 .550 .070}{549.468 .089 .021} \times 100 \\
& =105,89 \%
\end{aligned}
$$
tabel berikut:

Berikut hasil analisis Rasio Efektivitas PAD Kabupaten Subang dapat terlihat pada

\begin{tabular}{|c|c|c|c|c|}
\hline Tahun & \multicolumn{2}{c}{ Target } & Realisasi PAD & Persentase \\
\hline $\mathbf{2 0 1 4}$ & $206.423 .025 .875,00$ & $262.619 .476 .530,00$ & $127,22 \%$ & Sangat Efektif \\
\hline $\mathbf{2 0 1 5}$ & $281.201 .689 .946,00$ & $314.047 .989 .351,00$ & $111,68 \%$ & Sangat Efektif \\
\hline $\mathbf{2 0 1 6}$ & $326.015 .455 .956,00$ & $360.621 .220 .370,00$ & $110,61 \%$ & Sangat Efektif \\
\hline $\mathbf{2 0 1 7}$ & $549.468 .089 .021,00$ & $581.810 .550 .070,00$ & $105,89 \%$ & Sangat Efektif \\
\hline
\end{tabular}

Sumber: LRA kabupaten Subang (diolah) 
Berdasarkan hasil perhitungan rasio efektivitas PAD yang tertera dalam tabel di atas, dapat diketahui anggaran PAD kabupaten Subang selalu mengalami kenaikan dari tahun 20142017. Kenaikan anggran PAD tersebut diiringi dengan selalu mengalami kenaikan realisasi PAD pada setiap tahunnya. Pada tahun 2014, anggaran PAD Kabupaten Subang sebesar Rp. 206.423.025.875 dengan realisasi PAD sebesar Rp. 262.619.476.530 yang berarti berada pada titik 127,2\%. Pada tahun 2015 anggaran dinakkan menjadi sebesar Rp. 281.201.689.946 dan realisasinya adalah sebesar Rp. 314.047.989.351 dengan nilai efektivitas 111,6\%. Pada tahun 2016 anggaran mengalami kenaikkan kembali menjadi sebesar Rp. 326.015.455.956 dengan realisasinya sebesar Rp. 360.621.220.370 namun pada nilai efektivitasnya mengamali penurunan dari tahun sebelumnya menjadi $110,6 \%$. Adapun pada tahun 2017, anggaran dinaikkan dengan relatif tinggi dari tahun sebelumnya menjadi sebesar Rp. 549.468.089.021 dengan realisasi sebesar Rp. 581.810.550.070 dengan nilai efektivitasnya sebesar 105,8\%.

Menurut uraian tersebut, hasil perhitungan pada rasio efektivitas PAD Pemerintah Kabupaten Subang dari tahun 2014-2017 telah dikatakan efektif karena pada dasarnya nilai rasionya telah melebihi $100 \%$. Hal ini disebabkan adanya potensi-potensi baru yang berkembang sehingga dapat dimaksimalkan dalam upaya meningkatkan PAD. Selain itu adanya evaluasi yang dilakukan setiap tahunnya dan juga pengawasan dari pimpinan akan memiliki dampak untuk tahun berikutnya sehingga menjadi lebih baik lagi.

\section{Simpulan}

Berdasarkan dari hasil analisis data yang telah diuraikan sebelumnya, maka dapat diambil kesimpulan bahwa kinerja keuangan Pemerintah kabupaten Subang pada tahun 20142017 berdasarkan rasio kemandirian keuangan daerah dapat dikategorikan rendah sekali. Selain itu, kinerja keuangan Pemerintah Kabupaten Subang pada tahun 2014-2017 jika dilihat berdasarkan rasio keserasian belanja modal dengan belanja operasional dapat dikatakan pemerintah Kabupaten Subang lebih cenderung mengutamakan belanja operasional dari pada belanja modal. Kemudian kinerja keuangan Pemerintah Kabupaten Subang pada tahun 20142017 berdasarkan rasio pertumbuhan keuangan daerah dapat dikatakan masih sangat rendah. Selanjutnya kinerja keuangan Pemerintah Kabupaten Subang pada tahun 2014-2017 berdasarkan rasio efisiensi PAD dapat dikatakan tidak efisien. Namun, kendati demikian kinerja keuangan Pemerintah Kabupaten Subang pada tahun 2014-2017 ditinjau dari rasio efektivitas pendapatan asli daerah berjalan efektif karena efektivitasnya sudah di atas $100 \%$ yaitu masingmasing sebesar: $127,2 \% ; 111,6 \% ; 110,6 \%$; dan 105,8\%. 


\section{Referensi}

Adhiantoko, H. (2013). Analisis Kinerja Keuangan Pemerintah Kabupaten Blora (Studi Kasus Pada Dinas Pendapatan dan Pengelolaan Keuangan dan Aset Daerah Kabupaten Blora Tahun 2007-2010. Yogyakarta: Program Studi Akuntansi Fakultas Ekonomi Universitas Negeri Yogyakarta.

Anggara, S. (2015). Metode Penelitian Administrasi. Bandung: CV. Pustaka Setia

Fauziyah, S. (2017). Analisis Rasio Keuangan Pemerintah Kota bandung Tahun Anggaran 2014-2016. Bandung: Program Studi Adminisrasi Publik Fakultas Ilmu Sosial dan Ilmu Politik Universitas Islam Negeri Sunan Gunung Djati Bandung.

Halim, A. (2017). Akuntansi Keuangan Daerah. Yogyakarta: Selemba Empat.

Halim, A. (2012). Manajemen Keuangan Daerah Edisi Revisi. Yogyakarta: UPP AMP YKPN.

Hikmawati, F. (2017). Metodologi Penelitian. Depok: PT Raja Grafindo.

Lilis, A. (2017). Analisis Kinerja Keuangan Pemerintah Kabupaten Sumedang Tahun 20122016. Bandung: Program Studi Adminisrasi Publik Fakultas Ilmu Sosial dan Ilmu Politik Universitas Islam Negeri Sunan Gunung Djati Bandung.

Mahmudi. (2016). Analisis Laporan Keuangan Pemerintah Daerah. Yogyakarta: STIM YKPN.

Mahsun, M. (2011). Akuntansi Sektor Publik Edisi Ketiga. Yogyakarta: BPFE.

Mahsun, M. (2016). Pengukuran Kinerja Sektor Publik. Yogyakarta: BPFE Yogyakarta.

Megawati, F. (2004). Analisis Perbandingan Penyajian Laporan Keuangan antar Perbankan Syari'ah dan Konvensional. Universitas Shanata Darma.

Munawir, A. (2014). Analisa Laporan Keuangan. Yogyakarta: Liberty Yogyakarta.

Musthofa, Y. (2018). Analisis Laporan Keuangan Untuk Menilai Kinerja Keuangan Pemerintah Daerah Kabupaten Purwakarta Tahun Anggaran 2014-2016. Bandung: Program Studi Adminisrasi Publik Fakultas Ilmu Sosial dan Ilmu Politik Universitas Islam Negeri Sunan Gunung Djati Bandung.

Nordiawan, D. \& Hertianti, A. (2014). Akuntansi Sektor Publik. Jakarta: Salemba Empat.

Nuraeni, N. (2016). Analisis Rasio Kinerja Keuangan Badan Pengelolaan Keuangan Pemerintah Daerah Kabupaten Bekasi Tahun 2012-2016. Bandung: Program Studi Adminisrasi Publik Fakultas Ilmu Sosial dan Ilmu Politik Universitas Islam Negeri Sunan Gunung Djati Bandung.

Pasolong, H. (2013). Metode Penelitian Administrasi Publik. Bandung: Alfabeta.

Peraturan Pemerintah Nomor 71 tahun 2010 tentang Standar Akuntansi Pemerintahan.

Rifqi, M. (2011). Akuntansi Keuangan Syariah Konsep dan Implementasi PSAK Syariah. Yogyakarta: P3EI Press.

Rosidin, U. (2015). Otonomi Daerah dan Desentralisasi. Bandung: Pustaka Setia.

Sugiyono. (2012). Metode Penelitian Administrasi. Bandung: Alfabeta.

Sumarsono, S. (2010). Manajeman Keuangan Pemerintahan. Jember: Graha Ilmu. 
Suwanda, D. (2015). Sistem Akuntansi Akrual Pemerintah Daerah. Jakarta: Ikrar Mandiriabadi.

Tanjung, A. H. (2014). Akuntansi Pemerintah Daerah Berbasis Akrual: Pendekatan Teknis Sesuai PP No 71/2010. Bandung: Alfabeta.

Suparman, N. (2017). Evaluasi Pelimpahan Sebagai Kewenangan Bupati Kepada Camat di Kecamatan Sagalaherang. Subang. Jurnal Politik Indonesia.

Undang-undang Nomor 17 Tahun 2003 tentang Keuangan Negara

Undang-undang Nomor 23 Tahun 2014 tentang Sistem Pemerintahan Daerah.

Utomo, D. P. (2011). Analisis Rasio Keuangan APBD sebagai Tolak Ukur Penilaian Kinerja Keuangan Pada Pemda Kabupaten Lombok timur Tahun Anggaran 2007-2009. Jurnal Educatio, 4, 57-80.

Wahyuddin, I. (2017). The Application of accounting Zakat on The Center of Rumah Zakat Indonesia Foundation Bandung. Program studi Ekonomi Islam Fakultas Ilmu Agama Islam Universitas Islam Indonesia Yogyakarta. 